\title{
Optimal growth conditions and economic analysis of sea cucumber releasing
}

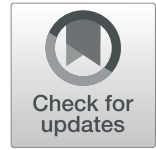

\author{
Cheol Lee ${ }^{1}$ and Sang Duk Choi $^{2^{*}}$ (D)
}

\begin{abstract}
We tried to find the optimal growth conditions of sea cucumber and to analyze the economic effectiveness of the sea cucumber seedling release project in Korea. We first examined the optimal growth conditions of sea cucumber in the relating literatures. Then, we analyzed the economic effectiveness of the sea cucumber seedling release project of the Woncheon fishing village union of Gyeongnam Province in 2016-2018 by using the cost benefit analysis method. The net income of the release project of the Woncheon fishing village union was 69,850 Korean won. The benefit to cost ratio of the sea cucumber seedling release project of the Woncheon fishing village union was estimated to be 1.7, indicating that the project was economically feasible. In order to improve the economic feasibility of the sea cucumber release project, as we see in the case of the Woncheon fishing village union, it is necessary to manage the purchase of the sea cucumber seedling, to improve the recapture rate of sea cucumber, and to manage marketing of sea cucumber.
\end{abstract}

Keywords: Sea cucumber, Optimal growth condition, Effectiveness, Seedling release

\section{Background}

Recently, due to the economic importance of sea cucumber, technological developments on artificial seed production and aquaculture have been carried out in many countries including Korea, China, and Japan. Even though China has some challenges restricting development of the sea cucumber industry, which includes weaknesses in the basic biological research, the issue of germplasm degradation, environmental stress caused by global climate change, and food safety issues. The production of Apostichopus japonicus has become commercially lucrative and successful after nearly 30 years of development ( $\mathrm{Ru}$ et al. 2019). Apostichopus japonicus is mainly distributed in the northern waters of the western Pacific, including the Bohai Sea and Yellow Sea of China, as well as the eastern coast of Russia and the coasts of Japan and South Korea (Yanagisawa 1998, Zhang et al. 2017). Now the Japanese sea cucumber, Apostichopus japonicus is the most

\footnotetext{
* Correspondence: choisd@jnu.ac.kr

${ }^{2}$ Division of Marine Technology, Chonnam National University, Yeosu 59626, South Korea

Full list of author information is available at the end of the article
}

economically important and valuable species in China $(\mathrm{Ru}$ et al. 2019).

In terms of supply and demand of sea cucumber, China's sea cucumber consumption was 200,969 tons in 2014, which exceeded its supply (China Fishery Group 2015). Now, China is looking for alternative sea cucumber farms in Russia, Japan, and North Korea and is attempting joint sea cucumber farming in South Korea. In Japan, in response to the growing demand for dried sea cucumber in China and other countries, large-scale fisheries companies are, in connection with village fisheries, expanding the sea cucumber production (Aoki Prefecture Fisheries Technology Center 2012a). In Korea, sea cucumber production reached 2491 tons in 1990, which declined due to shrinking habitats caused by pollution of coastal fisheries and coastal landfills, resulting in 833 tons in 2002 (Kang et al. 2012). However, sea cucumber production increased, through the release and aquaculture of sea cucumber seedlings, to 2045 tons in 2017 (Korean Statistical Information Service 2019).

In order to solve the shortage and price increase of sea cucumbers, sea cucumber seedlings have been released 
and farmed in Korea, China, and Japan, and research on the optimum growth environment of sea cucumber has been carried out to enhance the effectiveness of such releases. In this study, we try to find the optimal growth conditions of sea cucumbers by examining various relating literature in Korea, China, and Japan, and suggest the results with respect to the factors that compose the habitat environments. Then, we analyze the effectiveness of a sea cucumber release project in Korea using the sea cucumber seedling release project of the Woncheon fishing village union of Gyeongnam Province in 2016-2018.

In Korea, sea cucumbers are released by individual fishers, and fishing village unions subsidized by central and local governments in sites considered to satisfy the optimal growth conditions of sea cucumbers. Subsidies to releasing of sea cucumbers are usually given to a couple of fishing village unions representing one province. Then, the subsidies are offered to other fishing village unions or other regions in the province if they are economically feasible. The Woncheon fishing village union or Woncheon village is one of the representative releasing sites designated by Gyeongnam Province in 2016-2018. The results of the feasibility analysis of the releasing project by Woncheon fishing village unions are important because, as mentioned earlier, the subsidized releasing project of sea cucumber can be extended to the fishing village unions or other areas that satisfy the optimal growth conditions of sea cucumbers in Gyeongnam Province.

\section{Methods}

\section{Examination of optimal growth conditions for sea cucumber}

In order for the released sea cucumbers to settle stably and grow rapidly, various environmental conditions must be suitable for the habitat or site of release. Some of the factors that compose the habitat environments favorable to growth of sea cucumbers include water temperature, salinity, depth of water, velocity of water current, and quality of the substrate or farming site. We examined the optimal growth conditions of sea cucumber in the relating literatures in in Korea, China, and Japan.

\section{Cost and benefit analysis}

The cost and benefit analysis method is used to analyze the economic feasibility of the sea cucumber discharge project in Woncheon fishing village union of Gyeongnam Province. The cost of purchasing and releasing sea cucumber seedlings is used as a cost in B-C analysis. The collecting or harvesting cost, which is the cost of collecting the sea cucumber after the growth period of about 2 years, should be included as a cost, if the individual business operators or the fishing villages implement the discharge project by themselves and hire the harvesters to collect the sea cucumber after the growth period. However, if the municipal, provincial, or central government carry out seedling discharge project and the produced sea cucumber is collected by the harvesting company and distributed at a certain agreed rate between the fishing village and the harvesting company, the harvester's share will not be counted as a cost in the B-C analysis because the share will be the harvester's income. As was stated earlier, the harvesters take $45 \%$ of the harvest and the fishing village takes $55 \%$ of the harvest.

The benefit required for the B-C analysis is the amount of production that can be gained from the sales of sea cucumber. If individual business operators or fishing villages directly collect the released sea cucumber and sell them, the total amount of the sea cucumber production will be the direct income of the individual business operators or the fishing village. However, when the fishing village produces sea cucumber by hiring harvesters instead of collecting the sea cucumber directly, and distributes the produced sea cucumber at a certain rate with the harvesters, the benefit of the sea cucumber seed release project is the total production amount of sea cucumber. The distribution ratio between the fishing village and the harvester multiplied by the total production amount will be their respective income.

In order to calculate the benefit of sea cucumber discharge, we first estimate the yield of the resources by examining the release of the sea cucumber, the growth period, the final average weight at the time of final harvest, and the recapture rate, which is the ratio between initial discharge and final harvest. The equation can be given as follows:

$$
Q=N \times R \times W
$$

where

$Q$ is the quantity of production

$N$ is the number of cucumber released

$R$ is the recapture rate

$W$ is the average weight

As shown in the above Eq. (1), in order to increase the production of sea cucumber, the value of each variable constituting the production amount should be increased. In order to increase the recapture rate, the survival rate of the released sea cucumber should be high, and the sea cucumber should not move away and stay in the vicinity of the release sites, so that efforts and costs for harvesting should not increase. If the sea cucumber cannot be recovered from the place where the sea cucumber have been released, the final recapture rate of released cucumber will be very low and the production amount of sea cucumber and the economic effectiveness of sea cucumber seedling release will be significantly lowered. 
When the production of sea cucumber is estimated, the market price of sea cucumber is multiplied, and the total production amount of sea cucumber, which is a benefit required for economic analysis, can be obtained.

$$
A=Q \times P
$$

where

$A$ is the aggregate production amount

$Q$ is the quantity of production

$P$ is the average market price

When the total production amount of sea cucumber is obtained, it can be compared with the sea cucumber seedling release cost, from which the economic effect can be obtained. The equation can be given as follows.

$$
\mathrm{EE}=(B-C)=A-C
$$

or

$$
\mathrm{EE}=(B / C)=A / C
$$

where

$(B-C)$ is the difference between benefits and costs of sea cucumber seedling release.

$(B / C)$ is the benefits and cost ratio of sea cucumber seedling release

$A$ is the total amount of sea cucumber

$C$ is the costs of sea cucumber seedling discharge project

\section{Premise of analysis}

The release of sea cucumber seedling by Woncheon fishing village union of Gyeongnam Province was carried out several times from 2014 to 2018 and the harvest of sea cucumber was carried out between 2014 and April 2019. We considered the case that the release of sea cucumber seedling was carried out on 2 May 2017, and the harvest of sea cucumber was carried out between November 2018 and April 2019, for which the economic feasibility of the sea cucumber release project was examined. The release cost of sea cucumber seedlings released in 2017 was KRW 180 million and the number of released stocks reached 370,849. In the case of Woncheon fishing village union, harvesting of sea cucumber was handled by the harvesters, and $45 \%$ of the harvested sea cucumbers are distributed to the harvesters, so they are not included in the harvest costs. The recapture rate of sea cucumber from November 2018 to April 2019 was 51.2\%, and the average weight was $168.9 \mathrm{~g}$. The price of sea cucumber was assumed to be KRW $9500 / \mathrm{kg}$, reflecting the price of sea cucumber from 2017 to 2019.

\section{Data collection}

Woncheon fishing village union has received public support for the release of sea cucumber seedlings since 2014. The members of the fishing village union had installed natural rocks in the left and right coasts of the Woncheon port and carried out the project for release of sea cucumber seedlings. And they have been experiencing an increase in the production of sea cucumber since then. The release of sea cucumber seedlings from 2014 to 2018 is shown in Table 1 below.

The Woncheon fishing village union contracts the sea cucumber harvesting with woman divers and the diving apparatus fishery (DAF) divers on every 2 to 3 years and allows them to collect sea cucumber. The cost of purchasing the sea cucumber seedlings is borne by the Woncheon fishing village union. While the seedlings are growing after release, the harvesters are responsible for the custody and harvest of the sea cucumber. After the sea cucumber is harvested, the harvesters take $45 \%$ of the harvest and the fishing village takes $55 \%$ of the harvest. More than $50 \%$ of the sea cucumber harvests are sold by free sales system and the rest are sold by obligatory sales system. The price of sea cucumber was higher than KRW 10,000/kg until 2015, but it has been declining since then, reaching KRW 9000 10,000/kg in 2019 .

\begin{tabular}{|c|c|c|c|c|c|c|c|c|c|c|}
\hline \multirow{2}{*}{$\begin{array}{l}\text { Project } \\
\text { year }\end{array}$} & \multirow[t]{2}{*}{ Release date } & \multirow[t]{2}{*}{ Distributer } & \multirow{2}{*}{$\begin{array}{l}\text { Release } \\
\text { (unit) }\end{array}$} & \multirow{2}{*}{$\begin{array}{l}\text { Unit } \\
\text { price (Won) }\end{array}$} & \multicolumn{6}{|c|}{ Release cost (KRW 1000) } \\
\hline & & & & & $\begin{array}{l}\text { Total } \\
\text { sum }\end{array}$ & $\begin{array}{l}\text { Subsidy } \\
\text { total }\end{array}$ & $\begin{array}{l}\text { National } \\
\text { subsidy } \\
(48 \%)\end{array}$ & $\begin{array}{l}\text { Provincial } \\
\text { subsidy } \\
(12 \%)\end{array}$ & $\begin{array}{l}\text { County } \\
\text { subsidy } \\
(30 \%)\end{array}$ & $\begin{array}{l}\text { Self- } \\
\text { burden } \\
(10 \%)\end{array}$ \\
\hline 2014 & 2014 December 17 & $\begin{array}{l}\text { Angang Bay } \\
\text { Sea Fishery } \\
\text { Cooperative }\end{array}$ & 253,494 & 470 & & & & & & \\
\hline 2015 & 2016 April 12 & Namhae Fishery & 439,589 & 389 & 180,000 & 162,000 & 86,400 & 21,600 & 54,000 & 18,000 \\
\hline 2016 & 2017 May 02 & Namhae Fishery & 370,849 & 482 & 180,000 & 162,000 & 86,400 & 21,600 & 54,000 & 18,000 \\
\hline 2017 & 2018 April 27 & $\begin{array}{l}\text { Badagil, } \\
\text { (Co. Limited) }\end{array}$ & 455,651 & 353.7 & 161,109 & 144,999 & 77,333 & 19,333 & 48,333 & 16,110 \\
\hline 2018 & 2018 December 06 & Daebak Fishery & 268,380 & 345 & 92,591 & 83,332 & 44,444 & 11,111 & 27,777 & 9259 \\
\hline
\end{tabular}
The production of sea cucumber, the amount of

Table 1 Release of sea cucumber seedlings of Woncheon fishing village Union 
production, and the unit price per kilogram from 2012 to 2018 are shown in Table 2 below.

\section{Results \\ Optimal growth conditions for sea cucumber Korean case}

Water temperature is one of the most important ecological factors that affect growth and physiological processes in aquatic eurytherms. According to the 2014 Fisheries Seedling Management Project Guidelines, sea cucumbers grow most stably at $10 \sim 15^{\circ} \mathrm{C}$, begin to prepare for aestivation at $20^{\circ} \mathrm{C}$ or higher, and enter aestivation at the temperature up to $24^{\circ} \mathrm{C}$ (Korea Fisheries Resources Agency 2014a). However, if the water temperature persists above $28^{\circ} \mathrm{C}$, it is difficult for sea cucumbers to adapt to that temperature. Thus the habitat with the temperature higher than $28^{\circ} \mathrm{C}$ is considered unsuitable for released sea cucumbers (Korea Fisheries Resources Agency 2014b). Lee et al. (2018) regarded the water temperature, $10 \sim 15^{\circ} \mathrm{C}$ as suitable for growth of sea cucumbers. Unlike others, however, Jeong et al. (2019) reported that sea cucumbers grow even at the temperature higher than $28^{\circ} \mathrm{C}$. For salinity, 28 34 psu was reported to be suitable for a habitat for the released sea cucumbers (Kang et al. 2012). Lee et al. (2018) also reported salinity levels of $28 \sim 34$ psu as appropriate salinity.

For water depth, 5 10 m was reported as a suitable depth for the released sea cucumbers in the development project of sea cucumber island in Yangyang-gun, Korea (Korea Fisheries Resources Agency 2013a). In addition, 5 20 $\mathrm{m}$ was reported as a suitable depth for the released sea cucumbers in the sea cucumber aquaculture guidebook (Ministry of Agriculture, Food and Rural Affairs 2011). In the plan report for the establishment sea cucumber aquacultural complex, the depth less than $30 \mathrm{~m}$ was reported as a suitable depth (Korea Fisheries Resources Agency 2013b). Lee et al. (2013)

Table 2 Annual production of sea cucumber, production amount, and unit price per kilogram

\begin{tabular}{llll}
\hline Year & $\begin{array}{l}\text { Production volume } \\
(\mathrm{kg})\end{array}$ & $\begin{array}{l}\text { Production amount } \\
\text { (KRW 1000) }\end{array}$ & $\begin{array}{l}\text { Unit price/kg } \\
\text { (KRW 1000) }\end{array}$ \\
\hline 2012 & 5400 & 88,211 & 16.34 \\
2013 & 6815 & 90,214 & 13.24 \\
2014 & 7457 & 87,295 & 11.71 \\
2015 & 8121 & 86,921 & 10.70 \\
2016 & 9456 & 80,129 & 8.47 \\
2017 & 14,400 & 100,800 & 7.00 \\
2018 ( June) & 13,100 & 91,700 & 7.00
\end{tabular}

The amount of production shown in the Table 2 is the amount of production that can be verified by the obligatory sales system, and the actual amount of production harvested is estimated to be more than the amount of production shown in the Table 2 reported $6 \sim 10 \mathrm{~m}$ as a depth suitable for sea cucumbers. Lee et al. (2018) also reported $5 \sim 10 \mathrm{~m}$ as the depth suitable for inhabit of sea cucumbers. For the velocity of water, less than $0.6 \mathrm{~m} / \mathrm{s}$ and less than $2 \mathrm{~m} / \mathrm{s}$ were reported as adequate velocity in Korea. Considering this, Lee et al. regarded $0.2 \sim 0.4 \mathrm{~m} / \mathrm{s}$ as adequate velocity (Lee et al. 2018).

The Ministry of Maritime Affairs and Fisheries reported the substrate with rock, sand, and mud as adequate for sea cucumber aquaculture. The Ministry of Agriculture, Food and Rural Affairs reported the substrate with rock, amber stone, and mud was adequate for sea cucumber aquaculture (Ministry of Agriculture, Food and Rural Affairs 2011). Korea Fisheries Resources Agency reported the substrate with coarse gravel and sand as suitable for sea cucumber aquaculture (Korea Fisheries Resources Agency 2013c). Lee et al. (2013) reported the substrate with rock and muddy sand was adequate for sea cucumber aquaculture. Lee et al. (2018) also reported the substrate with rock, stone, and muddy sand with less than $20 \%$ sand in the substrate as adequate.

\section{Chinese case}

A few reports showed that empirically, Apostichopus japonicus could grow at a temperature range of $10 \sim 20^{\circ} \mathrm{C}$ (Sui 1990; Yu and Song 1999; Chen 2004; Yang et al. 2005). Dong et al. (2006) found that the optimum temperature for growth of Apostichopus japonicus was $15 \sim 18^{\circ} \mathrm{C}$. Based upon which, Ji et al. (2008) chose $20^{\circ} \mathrm{C}$ as optimal temperature for growth of sea cucumbers. The water temperature of $10 \sim 15^{\circ} \mathrm{C}$, was regarded as adequate in the cucumber farming areas in Shandong (Kang et al. 2012). Chen (2004), Yang et al. (2005) and Ji et al. (2008) chose $26^{\circ} \mathrm{C}$ as the threshold temperature to aestivation. The Yellow Sea Fisheries Research Institute reported that $70 \%$ of sea cucumbers of less than $85 \mathrm{~g}$ appeared at the depth of $1.7 \mathrm{~m}$ and $90 \%$ of sea cucumbers of more than $126 \mathrm{~g}$ appeared at the depth of $7.7 \mathrm{~m}$ (Kang et al. 2012). Choi (1963) reported that sea cucumbers of $50 \sim 100 \mathrm{~g}$ appeared at depth of $5 \mathrm{~m}$ and below, 100 150 $\mathrm{g}$ at depths of $5 \sim 10 \mathrm{~m}$, and $150 \sim 200 \mathrm{~g}$ at depths of $10 \sim 15 \mathrm{~m}$. The velocity of $0.5 \mathrm{~m} / \mathrm{s}$ or less was reported as adequate. For the substrate, it was reported that sea cucumber distribution was high at the habitat with low mud, and that reefs and sands with high sea algae and seagrass were adequate (Kang et al. 2012).

\section{Japanese case}

Aomori Fisheries Research Institute reported that the period when the water temperature was $2 \sim 10^{\circ} \mathrm{C}$ met the habitat conditions of released sea cucumbers (Aoki Prefecture Fisheries Technology Center 2012a, b). For water depth, the project to increase of releasing sea cucumber 
reported $10 \mathrm{~m}$ as the adequate for the release of sea cucumbers (Hokkaido Research Organization 2012). Lee et al. (2018) also considered 5 10 m suitable for growing sea cucumbers. For the velocity, the site with slow water flow was regarded as adequate. For the substrate, it was reported that sea cucumbers were distributed in the habitat with amber stone and sands, and less than $10 \%$ of mud, but sea cucumbers did not inhabit in the site with $27.8 \%$ or more of mud (Aoki Prefecture Fisheries Technology Center 2012a).

\section{Economic effectiveness of sea cucumber seedling release}

Based on the above analysis, the economic feasibility of the sea cucumber seedling release project in Woncheon fishing village union of Gyeongnam Province is as follows. The production of sea cucumber obtained using the released sea cucumber, recapture rate, and average weight of the harvested sea cucumber seedlings is 32, $070 \mathrm{~kg}$, and the total amount is KRW 307,044. The production cost of sea cucumber reaches KRW 180,000 which is sea cucumber seedling release fee. The economic effect of the sea cucumber seedling release project is as shown in the following Table 3.

The economic effectiveness of the sea cucumber seedling release project in Woncheon fishing village union is KRW 127 million, which is the total production amount of released sea cucumber with the release project cost subtracted. The fishing village union and the harvesters distribute the total production amount at a ratio of $55: 45$, so the net income of the fishing village union is KRW 69,850. The income of the harvesters reaches KRW 57,150. The benefit to cost ratio of the sea cucumber seedling discharge project in Woncheon fishing village union is estimated to be 1.7 , indicating that sea cucumber seedling release project is economically feasible.

When the price of sea cucumber and the price of sea cucumber seedlings are given as assumed, the breakeven point of the sea cucumber seedlings release project in Woncheon fishing village union in terms of recapture rate of sea cucumber is the point where the recapture rate is $30.25 \%$. When the recapture rate is higher than $30.25 \%$, the sea cucumber seedlings release project in Woncheon fishing village union will have the economic feasibility. On the other hand, when the recapture rate of sea cucumber and the price of sea cucumber seedlings are given as assumed, the break-even point of the sea cucumber seedling release project in Woncheon fishing village union in terms of the price of harvested sea

Table 3 Economic effects of the sea cucumber seedling release project in Woncheon fishing village union

Release cost Total production Economic Effectiveness $\mathrm{B}$ to $\mathrm{C}$ ratio (KRW 1000) $\quad$ (KRW 1000) $\quad$ (KRW 1000)

\begin{tabular}{llll}
\hline 180,000 & 307,044 & 127,044 & 1.7 \\
\hline
\end{tabular}

cucumber is the point where the price of harvested sea cucumber is KRW $5613 / \mathrm{kg}$. When the price of harvested sea cucumber is higher than the price, the seedling release project in Woncheon fishing village union will have the economic feasibility.

When the recapture rate of sea cucumber and the price of sea cucumber are given as assumed, the breakeven point of the sea cucumber seedling release project in Woncheon fishing village union in terms of the price of the sea cucumber seedling is the point where the price of the sea cucumber seedling is KRW 822 each. When the price of the sea cucumber seedling is lower than the price, the seedling release project in Woncheon fishing village union will have the economic feasibility.

\section{Discussion}

Optimal growth conditions for sea cucumber

The optimum growth conditions for sea cucumber were similar in all three countries, although there were some differences. The adequate water temperature is at $5 \sim 15{ }^{\circ} \mathrm{C}$ in Korea and China, but $2 \sim 10^{\circ} \mathrm{C}$ in Japan, of which lower limit is smaller than that of other two countries. For the water depth, $6 \sim 10 \mathrm{~m}$ seems to be appropriate in all three countries. The substrate with rock and muddy sand seems to be adequate in all three countries.

\section{Sensitivity analysis}

The cost and benefit of the sea cucumber seedling release project can be affected by the recapture rate, the price of the seedling, and the market price of the collected sea cucumber. Therefore, the sensitivity analysis should be performed to analyze the economic feasibility reflecting the change of the situations or conditions. The higher the market price of sea cucumber seedlings, the lower the mobility of sea cucumber and the higher survival rate of sea cucumber seedlings, the higher the economic effectiveness of sea cucumber seedlings release project.

According to the FIRA (Korea Fisheries Resources Agency), the $B$ to $C$ ratio of the sea cucumber release projects in Jeonnam Province and Gyeongnam Province in $2008 \sim 2010$ were 3.18 . The $B$ to $C$ ratio of the sea cucumber release projects in Chungnam Province, Gangwon Province, Gyeongbuk Province, Incheon City, Jeonnam Province and Gyeongnam Province in 2013 2014 was 1.45, indicating that both were effective. Park et al. (2013) analyzed the economic effects of the sea cucumber seedlings project in Gyeongbuk Province and found that the B to $C$ ratio was 2 , which is efficient. Sensitivity analysis also showed that the economic feasibility varied greatly depending on changes in recapture rate, market price, and seedling price. And it had been shown that there were cases in which the economic effectiveness was lost.

Sensitivity analysis was carried out for the range of 10 to $70 \%$ of recapture rate in consideration of the 
precedent cases to see how the economic effectiveness of the sea cucumber seedling release project in Woncheon fishing village union changes according to the change of the recapture rate. The analysis results are shown in the following Table 4.

As shown in Table 4, the economic feasibility of the project for the release of the sea cucumber seedlings decreases with the decrease in the recapture rate. If the recapture rate drops to the value less than $30.25 \%$, the economic effectiveness of the sea cucumber seedling release project in Woncheon fishing village union is negative, which means there is no economic feasibility. On the contrary, if the recapture rate increases, the economic effectiveness of the sea cucumber seedling release project in Woncheon fishing village union will be improved.

In order to improve the economic feasibility of the sea cucumber discharge project in the Woncheon fishing village union of Gyeongnam Province, it is necessary to increase the recapture rate of released sea cucumber. In order to raise the recapture rate, the survival rate of the seedlings must be high, and the sea cucumber should stay in the vicinity of the release sites, so that efforts and costs for harvesting should not increase. The survival rate of seedlings is related to the quality of seedlings and this is also related to the cost of seedlings. Therefore, the selection of seedlings should be based on the consideration of cost, quality, or survival rate.

In order to increase the recapture rate, the seedling should not move far away from release sites during the growing period, so that it can be harvested in large quantity at harvest time. In order to prevent the seedlings from moving far away, it is necessary to select the release sites with good nourishing environments. Park et al. (2013) also emphasized the importance of selection of release sites for the good results of the sea cucumber seedling release project in Gyeongbuk Province area. In addition, the cost for harvesting should be small, which will improve the economic feasibility by reducing the value of the cost in the benefit cost analysis.

Table 4 Sensitivity analysis for recapture rate

\begin{tabular}{llll}
\hline Recapture rate (\%) & $\begin{array}{l}\text { Economic effectiveness } \\
\text { (KRW 1000) }\end{array}$ & $\begin{array}{l}\text { Benefit to cost } \\
\text { ratio }\end{array}$ & Remarks \\
\hline 10 & $-120,495$ & 0.33 \\
20 & $-60,991$ & 0.66 \\
30 & -1486 & 0.99 \\
30.25 & 1 & 1.00 \\
40 & 58,018 & 1.32 \\
50 & 117,523 & 1.65 \\
51.2 & 124,663 & 1.69 \\
60 & 177,027 & 1.98 \\
70 & 236,532 & 2.31 \\
\hline
\end{tabular}

In order to see how the economic effect of the sea cucumber seedling release project in Woncheon fishing village union changes with the change of the sea cucumber price, the prices of sea cucumber from 2012 to 2019 are included in the sensitivity analysis. The price of sea cucumber ranged from KRW 5000 to KRW 20,000/kg. The results of the sensitivity analysis are shown in Table 5 below.

As shown in Table 5, the economic feasibility of the sea cucumber seedlings release project decreases as the price of sea cucumber falls. If the price of sea cucumber drops to the value less than KRW 5613, the economic effectiveness of the sea cucumber seedling release project in Woncheon fishing village union becomes negative. On the contrary, if the price of sea cucumber rises, the economic effectiveness increases.

Marketing management of the sea cucumber needed to improve economic effectiveness is an attempt to raise the shipping price of sea cucumber and increase the value of the benefit in economic analysis. Since the price of sea cucumber is determined by the market, the attempt cannot directly affect the price of sea cucumber, but the price of sea cucumber can be kept high by adjusting the shipping time and amount, and the economic effectiveness can be increased accordingly.

Sensitivity analysis was carried out for the case where the price of sea cucumber seedlings ranged from KRW 200 to KRW 1000 to see how the economic effectiveness of the sea cucumber seedling release project in Woncheon fishing village union changes according to the change of sea cucumber seedling price. The results of the analysis are shown in Table 6 below.

As shown in Table 6, the economic effectiveness of the sea cucumber seedlings release project decreases as the sea cucumber seed price rises. If the price of sea cucumber seedlings rises to the value higher than KRW 822, the economic effectiveness of the sea cucumber seedling release project in Woncheon fishing village union becomes negative. As the prices of sea cucumber seedlings declines, the economic effectiveness of the sea

Table 5 Sensitivity analysis of sea cucumber prices

\begin{tabular}{lll}
\hline $\begin{array}{l}\text { Price of sea cucumber } \\
\text { (KRW/kg) }\end{array}$ & $\begin{array}{l}\text { Economic effectiveness } \\
\text { (KRW 1000) }\end{array}$ & $\begin{array}{l}\text { Benefit to } \\
\text { cost ratio }\end{array}$ \\
\hline 2500 & $-99,825$ & 0.45 \\
5000 & $-19,651$ & 0.89 \\
5612.75 & 0 & 1.00 \\
7500 & 60,524 & 1.34 \\
9500 & 124,663 & 1.69 \\
10,000 & 140,698 & 1.78 \\
15,000 & 301,048 & 2.67 \\
20,000 & 461,397 & 3.56 \\
\hline
\end{tabular}


Table 6 Sensitivity analysis of sea cucumber seed price

\begin{tabular}{llll}
\hline $\begin{array}{l}\text { Unit price } \\
\text { (KRW) }\end{array}$ & $\begin{array}{l}\text { Economic effectiveness } \\
\text { (KRW 1000) }\end{array}$ & $\begin{array}{l}\text { Benefit to cost } \\
\text { ratio }\end{array}$ & Remark \\
\hline 200 & 230,494 & 4.11 \\
400 & 156,324 & 2.05 \\
485.37 & 124,664 & 1.69 \\
600 & 82,154 & 1.37 \\
800 & 7984 & 1.03 \\
821.53 & 0 & 1.00 \\
1000 & $-66,186$ & 0.82 \\
\hline
\end{tabular}

cucumber seedling release project in Woncheon fishing village union increases significantly.

In order to improve the economic feasibility of the sea cucumber release project in Woncheon fishing village union of Gyeongnam province, it is necessary to manage the purchase of the sea cucumber seedling, to improve the recapture rate of sea cucumber, and to manage marketing of sea cucumber. Through the adequate management of seedling purchase, the purchase cost of seedling can be lowered, which is possible by lowering the purchase price through mass purchase or adjustment of purchase timing. However, the purchase of hi-quality seedlings will increase the survival rate of the seedlings and contribute to the improvement of the recapture rate, which will raise the value of benefit in B-C analysis. Therefore, the purchase of good seedlings should not be comprised to lower the purchase price of seedlings.

\section{Limitation of this study}

Since the main purpose of this study was to verify the effectiveness of the sea cucumber seedling release program, not all the literature covering all aspects of the optimal growth conditions for sea cucumber was examined. In this study, only the optimal conditions regarding sea water temperature, depth, and the composition of substrate, which are some of the factors that indicate the optimal conditions of the sea cucumber release site were examined. In the future, it is necessary to study all aspects of the optimal growth conditions for sea cucumber.

This study examined the economic effectiveness of sea cucumber seedling release in a region on the south coast of Korea. Thus, it is not appropriate to expect that sea cucumber seedling release program in Korea will be effective based on these results. It would be more reasonable to determine that sea cucumber seedling release project in Korea would be effective after a review of the economic effectiveness of all the release program in various regions of the Korean coast.

In this study, the causal relationship between the economic effectiveness of sea cucumber releasing and the proper growth condition of sea cucumber was not addressed because of insufficient data for the relationship.
Therefore, what is needed more in this study is to find out how the optimal growth conditions of sea cucumbers affect the economic effectiveness of sea cucumber releasing, and thus further studies regarding this relationship are needed. In addition, a more detailed and extensive comparative studies of the optimal growth conditions of sea cucumbers in China, Japan, and Korea are needed to find out the factors pivotal to the growth of sea cucumbers and the relationship between those factors and economic effectiveness of sea cucumber releasing.

\section{Conclusions}

We tried to find the optimal growth conditions of sea cucumber and to analyze the economic effectiveness of the sea cucumber seedling release project in Korea. We first presented some optimal growth conditions of sea cucumber in Korea, China, and Japan by reviewing the relating literatures. Then, we presented the economic effectiveness of the sea cucumber seedling release project of the Woncheon fishing village union of Gyeongnam Province in 2016-2018 by using the cost benefit analysis method. The net income of the release project of the Woncheon fishing village union was 69,850 Korean won. The benefit to cost ratio of the sea cucumber seedling release project of the Woncheon fishing village union was estimated to be 1.7 , indicating that the project was economically feasible.

The sea cucumber release projects, which are carried out by the private sector with the help of the central and local governments of Korea, are carried out under tight budget constraints, so improving the economic feasibility of the release is essential to the success and sustainability of such release projects. In order to improve the economic feasibility of the sea cucumber release project, as we saw in the case of the Woncheon fishing village union, it is necessary to manage the purchase of the sea cucumber seedling, to improve the recapture rate of sea cucumber, and to manage marketing of sea cucumber.

\section{Acknowledgements \\ Cheol Lee and Sang-Duk Choi contributed equally to this work.}

\section{Authors' contributions}

The authors contributed to this manuscript as follows: $\mathrm{CL}$ contributed to the design of the study and cost-benefit analysis and sensitivity analysis, and writing of the manuscript. CDC contributed to drafting and reviewing of the manuscript. All authors reviewed, edited, and approved the manuscript for submission.

\section{Funding}

Not applicable.

\section{Availability of data and materials}

The datasets used and/or analyzed during the current study are available from the corresponding author on reasonable request. 


\section{Competing interests}

The authors declare that they have no competing interests.

\section{Author details}

'Division of Logistics and International Commerce, Chonnam National University, Yeosu 59626, South Korea. ${ }^{2}$ Division of Marine Technology, Chonnam National University, Yeosu 59626, South Korea.

Received: 29 December 2019 Accepted: 7 February 2020

Published online: 10 April 2020

\section{References}

Aoki Prefecture Fisheries Technology Center. 2012a. The ecology and resource management of sea cucumber, Stichopus japonicas A. http://www.aomori-itc. or.jp/public/zoshoku/dayori/114g/114_p8-10.pdf. Accessed 15 Oct 2019.

Aoki Prefecture Fisheries Technology Center. 2012b. The releasing and seedling manual of sea cucumber, Stichopus japonicas B. https://www.aomori-itc.or. jp/_files/00093750/Namako_houryuu.pdf.

Chen JX. Present status and prospects of sea cucumber industry in China. In: Lovatelli A, Conand C, Purcell S, Uthicke S, Hamel JF, Mercier A, editors. Advances in sea cucumber aquaculture and management. Rome: FAO; 2004. p. 25-38.

China Fishery Group. The consumption of sea cucumber in China. Beijing: China Fishery Group; 2015. p. 19

Choi S. Study of sea cucumber, Stichopus japonicus. Tokyo: Kaibuto; 1963. p. 35.

Dong YW, Dong SL, Tian XL, Wang F, Zhang MZ. Effects of diel temperature fluctuations on growth, oxygen consumption and proximate body composition in the sea cucumber Apostichopus japonicus Selenka. Aquaculture. 2006;255:514-21.

Hokkaido Research Organization. The project to increase of releasing sea cucumber, Stichopus japonicus. Sapporo: Hokkaido Research Organization; 2012. p. 64

Jeong UC, Anisuzzaman M, Jin F, Choi JK, Han JC, Choi BD, Kang SJ. Effect of High Water Temperature on the Growth and Lipid Compositions of the Sea Cucumber Apostichopus japonicus. Korean J Fish Aquat Sci. 2019:52(4);400407. https://doi.org/10.5657/KFAS.2019.0400.

Ji T, Dong YW, Dong SL. Growth and physiological responses in the sea cucumber, Apostichopus japonicus Selenka: aestivation and temperature. Aquaculture. 2008;283:180-7.

Kang SJ, Kang SW, Kang JH, Jung WC, Jin SD, Choi BD, Han JC. Sea cucumber aquaculture technology. Seoul: Aquainfo; 2012. p. 426.

Korea Fisheries Resources Agency. The development project of sea cucumber island in Yangyang-gun A: Korea Fisheries Resources Agency, FIRA-PR-2013027; 2013a. p. 173.

Korea Fisheries Resources Agency. The plan report for the establishment of sea cucumber aquacultural complex: Korea Fisheries Resources Agency, FIRA-PR2013-032; 2013b. p. 119

Korea Fisheries Resources Agency. Eco-friendly seedling test of sea cucumber, Stichopus japonicas: Korea Fisheries Resources Agency; 2013c. p. 266.

Korea Fisheries Resources Agency. 2014 Fisheries seedling management guidelines: Ministry of Oceans and Fisherie, FIRA-PR-2014-050; 2014a. p. 35.

Korea Fisheries Resources Agency. Estimation of optimum releasing rate of sea cucumber, Stichopus japonicas: Korea Fisheries Resources Agency, FIRA-PR2014-022; 2014b. p. 61.

Korean Statistical Information Service. 2019. Production amount of sea cucumber in Republic of Korea from 1990 to 2019. http://www.kostat.go.kr. Accessed 18 Dec 2019.

Lee CH, Lee DH, Kwak SN, Kim HW. A preliminary study in habitat characteristics and settlement of released sea cucumber, Stichopus japonicus in the coastal waters of Korean peninsula. J Fish Resour Manag. 2013;3:113-27.

Lee JW, Gill HW, Lee DH, Kim JK, Hur JW. Variations of size and density of sea cucumber (Stichopus japonicus) released to the habitat conditions. Ocean Polar Res. 2018;40(2):69-75.

Ministry of Agriculture, Food and Rural Affairs. The guidebook for aquaculture of sea cucumber, Stichopus japonicas, vol. 134. Sejong: Ministry of Agriculture, Food and Rural Affairs; 2011.

Park KI, Kim YJ, Kim DH. Analyzing Economic Effectiveness of the Sea Cucumber Seed Releasing Program in Gyeongsangbuk-do Region. Journal of Fisheries Business Administration. 2013;44(1);81-90. https://doi.org/10.12939/FBA.2013. 44.1.081.
Ru XS, Zhang LB, Li XN, Liu SL, Yang HS. Developing strategies for the sea cucumber industry in China. J Oceanol Limnol. 2019;37(1):300-12. https://doi. org/10.1007/s00343-019-7344-5.

Sui X. Culture and enhance of sea cucumber. Beijing: China Agriculture Publishing House; 1990. (In Chinese).

Yanagisawa T. Aspects of the biology and culture of the sea cucumber. In: Tropical mariculture. London: Academic; 1998. p. 291-308.

Yang HS, Yuan XT, Zhou Y, Mao YZ, Zhang T, Liu Y. Effects of body size and water temperature on food consumption and growth in the sea cucumber Apostichopus japonicus (Selenka) with special reference to aestivation. Aquac Res. 2005;36:1085-92.

Yu DX, Song BX. Variation of survival rates and growth characteristics of pond cultural juvenile Apostichopus japonicus. J Fish Sci China. 1999;6:109-10 (In Chinese with English abstract).

Zhang XF, Liu Y, Li Y, Zhao XD. Identification of the geographical origins of sea cucumber (Apostichopus japonicus) in northern China by using stable isotope ratios and fatty acid profiles. Food Chem. 2017;218:269-76.

\section{Publisher's Note}

Springer Nature remains neutral with regard to jurisdictional claims in published maps and institutional affiliations.

Ready to submit your research? Choose BMC and benefit from:

- fast, convenient online submission

- thorough peer review by experienced researchers in your field

- rapid publication on acceptance

- support for research data, including large and complex data types

- gold Open Access which fosters wider collaboration and increased citations

- maximum visibility for your research: over $100 \mathrm{M}$ website views per year

At BMC, research is always in progress.

Learn more biomedcentral.com/submissions 